\title{
Sociocultural peculiarities of manipulation of public consciousness in the USA and Russia
}

\author{
Anna Valerievna Chaykisova ${ }^{1, *}$, and Olga Vladimirovna Kuznetsova ${ }^{1}$ \\ ${ }^{1}$ Irkutsk State University, Department of Oriental and Asia-Pacific Studies, 664000, Irkutsk, Russia
}

\begin{abstract}
The article offers a comparative analysis of myths disseminated in American and Russian public discourse. The authors argue that the way myths are used as a tool of manipulating public consciousness depends on a number of social and cultural peculiarities of Russia and the USA. We demonstrate that manipulation through myths is based on universal cognitive mechanisms; therefore, both countries may use similar myths to achieve particular goals in governmental interests. On the other hand, effective manipulation becomes possible when ideas rendered by myths are understandable and appealing to a particular nation or group of people at a particular moment. Given that, political leaders of both countries manage to shape the way people understand themselves and their country in relation to the world. It helps them to maintain their interests in domestic and foreign policy.
\end{abstract}

\section{Introduction}

Manipulation of public consciousness is not a new concept. No one doubts that it is often used as an instrument of power, though; it is constantly being transformed with the changes in the societies and cultures. Although a great deal has been written about manipulation, most studies have mainly focused on its general features but have not considered that it could vary across regions and cultures. The aim of the article is to figure out and analyze whether Russia and the USA, regarded as regions, demonstrate any specific features of manipulation related to their sociocultural background. The most vivid tool of manipulation associated with this background is myth-making.

Traditional myths as stories, concerning the early history of a people or explaining a natural or social phenomenon, are used as an instrument for understanding the society, helping people to explain the chaotic world around them. Such myths represent the perception of the nation by itself and the world. The modern political myth is said to concern "specific aspects of social (political) reality, to which it attributes special characteristics (transcendental, sacral). It constructs distinctive mythic narratives that directly serve certain political goals" [1]. Moreover, modern myths are defined as "beliefs that claim the right to shape the social world and sometimes even manage to influence it. In this case, they often take on a pejorative meaning, becoming the means of manipulating the society or restricting the freedom of the individual" [2].

\section{Theoretical backgrounds}

In this article we analyze myths as ideas shared by members of a particular society, which are considered to be the absolute truth. What we call manipulation here is "a communicative and interactional practice, in which a manipulator exercises control over other people", makes "others believe or do things that are in the interest of the manipulator, and against the best interests of the manipulated" [3]. From this perspective, manipulation through myths aims at influencing public consciousness covertly in order to change people's beliefs and actions in a beneficial for the manipulator direction. Thus, this process involves the transformation of specific ethnic, social and cultural characteristics, such as opinions, beliefs, stereotypes, values, attitudes, etc. It seems to work as a particular programming of mind, hence, should be studied in the cognitive framework. V. Dijk, for example, talks about mental models and social shared representations, emphasizing that they are manipulated in order to control what people do and say [3]. O.V. Lange describes it as national mentality [4]. Though such related concepts as 'national mentality', 'national psychology' are often criticized, we cannot but acknowledge that there are specific features of cultures and societies that determine the way they perceive themselves, other people, and the world around. On the one hand, these specific features are acquired by people in the natural processes of upbringing, education, socialization, etc. On the other hand, they can be deliberately construed or transformed in someone's interests.

Despite the process of globalization and the presence of some common characteristic features, Russia and

Corresponding author: anncher@ rambler.ru 
the USA are often represented as having certain cultural differences, and are still compared as Eastern and Western cultures, demonstrating holistic vs. analytical thinking, having collective vs. individual, feminine vs. masculine cultural values (acc. to Hofstede dimensions), a society with high scores in secular-rational and survival values vs. a society with high scores in traditional and self-expression values (acc. to InglehartWelzel Cultural Map). Moreover, they have different political regimes as well as their own historical heritage. These differences may explain the use of particular myths as instruments of manipulation in these regions.

Myths as inherent parts of any culture sustain certain attitudes and reproduce a particular behavior because they are based on and appeal to collective archetypal structures, irrational mechanisms and deeply rooted subconscious symbols and images, thus, they have to do with collective unconscious. We need to emphasize this irrational character of myths because it distinguishes them from other tools of manipulation. Moreover, due to this they can be viewed as "the symptoms of an irrational force that stems from the consciousness of a common race and descent, traditions, language, the feeling of belonging to the same community" and "the symptoms of common identities" [5].

It is necessary to mention that myth can serve progressive and regressive politics alike, where the latter stems primarily from its irrational and practical character. The cohesive and integrative function of myths is that they enable the creation of the fundamental self-image and purpose, and provide a sense of the past as well as a direction for the future. However, myths can reflect and propagate false and misleading ideas. Political myths then serve to justify the political power/regime and its actions, i.e. to conceal and blur social reality [1]. Discussing other functions of myths, G. Kibris points out that with the help of political myths "the anxieties of both the ruler and ruled could be solved, emotions could be controlled, radical changes could be promoted, certain memories could be maintained, political choices could be manipulated, and finally national identities could be constructed and maintained" [6].

Accordingly, the concepts of manipulation, political myths and ideology are interconnected and interrelated. Christopher G. Flood characterizes contemporary myth as "ideology cast in the form of story," and says that "the delights of narrative help to naturalize and legitimize prevailing ideological assumptions so that they seem inevitable and universally applicable" [7]. Therefore, those who create and control political myths have a real power [1].

\section{Discussion}

\subsection{Myths and manipulation in the USA}

American society with its Western origin, individualist and masculine cultural values and analytical type of thinking gave rise to the promotion of democratic values through basic political myths: American exceptionalism, American dream, American democracy as universal good, etc.

The core foundational myth the American nation and American identity have been constructed by is the conception of American exceptionalism. It is defined as the idea that the United States is a singular, superior, and perhaps even God-favored country in the international community [8]. This idea is historically predetermined. From the very beginning Americans had to demonstrate and maintain their cultural and political independence and this idea also helped them to build their national identity, to create internal solidarity, to symbolize and affirm the US nation. However, U.S. political leaders have been using it in their own interests both locally and globally. For example, claims about America's special status were used to justify Manifest Destiny, the creation of the League of Nations, the use of nuclear bombs in Japan, and the Bush Doctrine [9]. Recently the myth has often been used as an ideological tool to legitimate American hegemony outside the US. The analysis of the American public discourse shows that public consciousness has been manipulated by the following ideas based on the myth of American exceptionalism: "the USA has a special mission on earth", "it stands as the world's exceptional power", "it is a global power", "it is innocent", "it never commits crimes, but is a victim", and "it is a nation saving others". Thus, people believe that the USA has the right to interfere into other state's internal affairs, set international policies, influence other countries to sign treaties, maintain peace between warring countries and is free from the supervision of international institutions. This somehow helps to legitimize the American engagement in the wars in Vietnam and Iraq, the refusal to participate in the Kyoto Protocol, etc.

The myth of American exceptionalism is connected with other myths and thus, works as an umbrella one. From the economic perspective, it refers to another powerful American myth, i.e. the idea of American dream and its related concepts of "the self-made man", "from rags to riches", "equality of opportunity", "expressive individualism", and "meritocracy". This myth is often associated with promises of a better life to all people who come to the US, and thus commonly considered to be an immigrant myth. The most widely spread examples of self-made African Americans are the media personality Oprah Winfrey and the 44th president of the United States Barack Obama. Their images are often to manipulate public consciousness. Barack Obama, in his turn, used the myth of the self-made man in many of his speeches. On the one hand, it seems that there is nothing bad about the idea that if one works hard, he can become successful, but on the other hand, there arise some problems. First, the myth forces people to strive for success, believe in status symbols, take loans they cannot pay off, thus, their pursuit of happiness becomes the pursuit of property. Moreover, "even for fortunate Americans, the recession that battered world economies in 2008 made maintaining the comfortable lifestyle of the middle class seem dependent less on hard work than on global economic forces like the price of crude oil and the migration of American jobs overseas" 
[10]. Studies also show that it is almost impossible for Americans to escape poverty: 95 percent of children born to poor parents will themselves be poor all their lives [10]. These myths are used to legitimize social inequalities and the US economic system as a whole.

The idea that the United States is an exceptional nation is a favored theme in U.S. presidential discourse [9], for example, in his appeal to the American public on September 10, 2013 President Barack Obama turned to it to justify military activities in Syria. Joe Biden now promises to restore America's global and moral leadership. Donald Trump also exploited the idea of American Exceptionalism but in a bit different way: to elevate not the nation, but himself personally, professionally, and politically; he broke with tradition and instead of championing American exceptionalism, he actively portrayed the nation as an un-exceptional mess in need of a saviour setting himself up to be seen as the one person who could "Make America Exceptional Again." [11].

Nowadays myths are being implanted in the minds of American people not only by traditional channels as church, school, and media but also by mass culture. American film industry, for example, contributes a lot to the dissemination of different myths and stereotypes. Scholars have been studying the role played by the film industry in shaping American ideology in the public sphere. D. Meinel examines the ways in which the Pixar animation films reanimate such American myths and symbols as the myth of the American Dream in Ratatouille, The Frontier myth in WALL-E, the mediation of America Exceptionalism in Toy Story 3, and others [12]. J. Levinson shows that the American success myth is one of the most central and enduring national myths in the US that cinema has largely contributed to dissemination [13]. Studying American Exceptionalism in the Film Industry of the Middle Twentieth Century Br. Everett specifies that "the control of narrative is a crucial factor in maintaining public support for American engagement in foreign conflicts" [14].

To understand how the myths under consideration influence public consciousness in the USA we studied the results of different surveys concerning Americans' beliefs and attitudes towards their country and its international position. Their findings are similar, so they show that in general, Americans remain firm in their belief that American culture and the American way of life are superior to others. More than half (53 percent) of Americans say that the world would be much better off if more countries adopted American values and the American way of life [15]. It is interesting to note, however, that younger generations tend to be more internationally oriented, more favorably disposed to groups, leaders and countries beyond their border, and less likely to see the U.S. as exceptional. Around four-inten Boomers or Silent Generation members say the U.S. stands above all other countries in the world, while only around a quarter or fewer of Gen Xers (26 percent) and Millennials (22 percent) say the same [16]. We can find different explanations for these big generation differences in views about American exceptionalism.
There is a point of view that it is American education to blame as Anti-Americanism has spread across college campuses of American universities [17]. The results of the I\&I/TIPP poll surprisingly demonstrate that colleges and universities - which have become bastions of America-hating leftists - seem to be inadvertently instilling American pride in their students. The poll found that 75 percent of college graduates are proud to be an American, compared with 62 percent of those with only a high school diploma [18]. Thus, it is necessary to observe other factors besides education. For example, we may consider the cliché that you become more rightwing as you age [19]. The results of the poll also show that older people are simply more inclined to feel patriotic [18]. Some experts say that the 21 st century with the attack on the Twin Towers, the war in Iraq, the economic crisis of 2008, and now the COVID pandemic has not exactly provided any comparable experience that can serve as a source of national pride for Americans [19]. We agree that all these factors may have contributed to the scepticism about American status that young people demonstrate. But the most important factor, we believe, is that younger generations of Americans develop a different identity due to the way they communicate and get information in the digital world. Social media serve as the first source of information among young people. They have access to international news, they are aware of how the rest of the world perceives them, thus, developing a global outlook, they feel less of a connection to the U.S. because they are more able to be connected elsewhere. However, they are also subject to all sorts of computational propaganda, i.e. digital misinformation and manipulation. One example of this is the use of Internet memes that serve as a very powerful tool of manipulating public consciousness in modern digital political discourse. Moreover, "because of their strong narrative components, memes have potential to engage citizens on a mythic level. As a mode of hypersignification, they often draw attention to the unnatural underpinnings of dominant myths" [20]. For example, Condescending Wonka meme questions the stability of the American dream myth: "Oh so you believe in the American dream // I'm sure thousands of unemployed Americans do too". It suggests that the myth may not be an essential truth but rather "serves a political function by placating those whom the rising tide of economic growth leaves behind" [20].

\subsection{Myths and manipulation in Russia}

There are a lot of political myths in Russia which are determined by its specific history, social and cultural features, e.g. Moscow as the third Rome, Russia as the Sacred Empire, the Great Patriotic War, Sacred Past, Russia's particular way, etc. In this article we focus on the analysis of modern political myths spread in the Russian political discourse as a result of deliberate manipulation of public consciousness in governmental interests. The manipulation by the idea of Russia's special path can be explained by the reluctance of the 
Government to emulate American or Western models of development. Such traditional elements of Russian identity as Orthodox Christianity, some positively marked elements of the Soviet legacy, the most powerful of which is the myth of the Great Patriotic War, are also used to portray Russian society different from the liberal West. It is also in governmental interests to sustain traditional weakness of Russian society. As Russian people have lived in constant fear and submission, they developed such characteristics as apathy, distrust, low expectations, they tend to believe that that they cannot change anything, and in general remain highly atomized.

Some of the myths are used to legitimize Russian foreign policy goals. Let us consider the mythologization of personalities of Russian leaders (e.g. Vladimir the Great, Peter the Great, Catherine the Great, Vladimir Lenin, Joseph Stalin). Due to paternalistic cultural values, Russian people tend to worship a person in power, believe that he/she can drastically change the life in the country for the better. The personality of Russia's current president is also mythologized; he is presented in the media as a strong and competent leader of the country. People are constantly told about strong traits of his character, achievements of different kinds, they are shown pictures and videos where he is arm wrestling, riding a horse and practicing judo. As a result Vladimir Putin became known as "the leader of the nation". There appeared a number of myths concerning Putin's image: "all-powerful Putin", "Putin as dictator", "It's all about Putin - Russia is manually run, centralized autocracy". Putin's 'Direct Line' - an annual televised question-andanswer session during which the president hears from, and responds to, the problems of Russians across the country - helps to disseminate these myths. He is shown to make decisions alone and on the spot to solve callers' woes. He instructs officials to carry out these orders. And he engages directly with citizens, without the need for mediating institutions such as political parties or parliament. It is said to reinforce misperceptions of Russia, in two opposite ways: Putin is either seen as the 'good tsar', a more potent and unconstrained political force than in reality or it highlights the pathologies of personalized decision-making and thus supports cartoonish Putin-as-dictator characterizations in the West [21].

L.S. Nabokova states that the basic archetypal structures of the Russian collective unconscious include images of the leader/father-tsar, the archetypes of the hero and the enemy, archetypes of conciliarity, the Absolute and the Homeland. The image of the current President of Russia is represented in the mass consciousness also in the symbols of the Russian Orthodox royal dynasties [22].

There is another set of related myths widely spread in modern Russian political discourse: "Russia as elder brother", whose mission is to gather smaller nations around the Russian core [23], "The peoples of Ukraine, Belarus and Russia are one nation". These myths are used to legitimize Russian foreign policy goals, such as promoting the Eurasian Economic Union as an economic integration project equivalent to EU, to justify the Russia's right to interfere in the internal affairs of its neighbors. In the context of the annexation of Crimea in 2014 there appeared another myth - "Crimea was always Russian”. It was in the Kremlin's interests to make people believe that "Crimea legitimately and willingly seceded from Ukraine and joined Russia in 2014. The referendum organized by Russia was merely a smokescreen to formalize Russia's military takeover of the peninsula" [21].

However, the annexation of Crimea from Ukraine helped Putin to present himself as a leader who had returned the country to its place as a great power. In fact, the "Russia is great" rhetoric came back; Putin's popularity grew. According to the survey published at that time by the Levada Center, 86 percent of Russians approved Putin's performance as president [24]. The annexation of Crimea was called by some international journalists a triumph of political manipulation over national interests and common sense. Manipulation in this case was successful for several reasons. First, the myths it was based on rely on such features and cultural values of Russian character (mainly collectivist and feminine acc. to Hofstede) as heartfulness, compassion, dignity, fear of war, sense of injustice. Moreover, the flows of information, via television in particular, were strictly controlled. The films "Crimea", "Crime. Way to Motherland" were deliberately made and shown in Russia to influence public consciousness in a favorable for the Russian government way.

The data of the recent opinion poll concerning the role of Russia in the World conducted by VSIOM in May 2021 show that 65 percent of those polled evaluate this role positively. 43 percent of Russians think that Russia's influence in the world has recently grown [25].

\subsection{Russia and the USA: manipulating each other through myths}

Today the United States and Russia remain two major international actors having conflicting political interests. They both use myths concerning their images to manipulate each other and the global community. The myths they use most frequently are based on very powerful archetypal images of Persecutor, Victim, and Rescuer (see Karpan's Triangle). Russia represents itself as Savior (Rescuer in Karpan's terms) as it protects its neighbors, and its own values and cultures. The USA also pictures itself as Savior but in the context of protecting democratic values, such as liberty and human rights. Both countries represent each other as Persecutors. Russia blames the U.S for sanctions and interference on the global arena, the USA accuses Russia of undermining democratic principles and interfering in U.S. elections. The analysis shows that depending on its interest a country may use all these images. Another powerful image both countries actively use when constructing political myths is the image of external enemy. It is very easy to manipulate public consciousness using it, as naturally people tend to seek governmental protection and support from external enemies. This manipulation helps governments to keep power. What is more, today Russia and the USA portray 
each other in public political discourse as external enemies or threats. The USA says that Russia wants to erode trust in U.S. democratic institutions and to divide Americans by race and extreme ideology. Russia says that the USA destabilizes internal political and social situation, puts informational pressure on Russian people, undermining Russian spiritual and moral values.

The Levada survey of Russians' attitudes toward the United States shows that 40 percent of Russians feel good about America, 42 percent of Russians have a bad attitude toward the U.S. [26]. But when asked "Who would you say are enemies of Russia?" the majority name the USA. [27]. The percentage of Americans viewing Russia unfavorably is 73 percent. Americans are now more likely to name Russia than any other country as the nation they think is the United States' greatest enemy [28]. Views of Russia among young people are somewhat more positive [16].

\section{Conclusion}

The analysis shows that myth-making as a tool of manipulation is widely used both in the USA and Russia. There are some common features of this phenomenon, connected with universal cognitive mechanisms underlying it, like the use of archetypes, symbols, etc. What makes the manipulation through myths effective, however, is the fact that the ideas rendered by myths must be understandable and appealing to a particular nation/group of people at a particular moment. Only when manipulation through political myths is based on social and cultural peculiarities of the targeted audience, manipulators manage to shape the way people understand themselves and their country in relation to the world, thus, maintaining particular interests in domestic and foreign policy. The study demonstrates that as Russia and the USA have specific social, cultural, historical characteristics, they use either different myths or similar myths but in different ways. It proves the hypothesis that there are specific sociocultural peculiarities of manipulation, moreover, the analysis of these specific features may help to understand how people of Russia and the USA understand themselves and the role of their countries both domestically and internationally and consequently better the relationships between the regions.

\section{References}

1. N. Svilicic, P. Maldini, Coll. Antropol. 38, 2 (2014)

2. A. Ceglarska Krak.Stud. z Hist. Państ. i Pr. 11 (3) (2018)

3. T. A. v. Dijk SAGE Publ. 17, 2 (2006)

4. O.V. Lange Sovremennye manipuljativnye tehnologii [Modern manipulative technologies] $\mathrm{SPb}$ (2015)

5. Ch. Bottici, A Philosophy of Political Myth (Cambridge University Press, NY, 2007).

6. G. Kibris J. of Ab. Cult. Stud. 4, 7 (2019)
7. Ch. G. Flood, Political Myth: A Theoretical Introduction (Routledge, NY, 2002)

8. S. M. Lipset, American exceptionalism: A doubleedged sword. (W.W. Norton, NY, 1996)

9. J. Gilmore Comm. Stud. 66, 3 (2015)

10. G. Colombo, R. Cullen, B. Lisle, Rereading America: Cultural Contexts for Critical Thinking and Writing (Macmillan Learning, NY, 2016)

11. J. Gilmore, Ch. Rowling, Exceptional Me: How Donald Trump Exploited the Discourse of American Exceptionalism (Bloomsbury Publishing, NY, 2021)

12. D. Meinel, Pixar's America: The Re-Animation of American Myths and Symbols (Palgrave Macmillan, London, 2016)

13. J. Levinson, The American Success Myth on Film (Palgrave Macmillan, NY, 2012)

14. Br. Everett, Hist., Anthr. \& Philos. 7 (2017)

15. After the ballots are counted: Conspiracies, political violence, and American exceptionalism: Findings from the January 2021 American Perspectives Survey. Accessed on: August 22, 2021. [Online]. Available:

https://www.americansurveycenter.org/research/afte r-the-ballots-are-counted-conspiracies-politicalviolence-and-american-exceptionalism

16. U.S. Millennials tend to have favorable views of foreign countries and institutions - even as they age. Accessed on: July 12, 2021. [Online]. Available: https://www.pewresearch.org/facttank/2020/07/08/u-s-millennials-tend-to-havefavorable-views-of-foreign-countries-andinstitutions-even-as-they-age.

17. My generation is being raised to hate America - it's time to stand up for our history. Accessed on: August 10, 2021. [Online]. Available: https://www.usatoday.com/story/opinion/voices/202 0/09/23/1619-project-american-history-educationtrump-patriotic-column/5864265002/

18. I\&I/TIPP Poll: Just $36 \%$ of Young People Are Proud To Be American. Accessed on: August 8, 2021. [Online]. Available: https://tippinsights.com/ii-tipp-poll-just-36-of-young-people-are-proud-to-beamerican/

19. Why Millennials and Gen $\mathrm{Z}$ Aren't Proud to Be American URL: https://www.newsweek.com/patriotism-gapmillennials-gen-z-baby-boomers-gen-x-1611749

20. J. Carter, Enchanting Memes: Memetic Politics in the Face of Technocratic Control (University of Nebraska, Lincoln, 2016)

21. Myths and misconceptions in the debate on Russia How they affect Western policy, and what can be done. Accessed on: July 28, 2021. [Online]. Available:

https://www.chathamhouse.org/sites/default/files/20 21-05/2021-05-13-myths-misconceptions-debaterussia-nixey-et-al.pdf 
22. L. S. Nabokova, Russ. J. of Sib. Fed. Univ. Hum. \& Soc. Sc. 2 (2017)

23. M. Rywkin, Am. For. Pol. Int. 36, 3 (2014)

24. Ijun"skie rejtingi odobrenija i doverija Accessed on: July 30, 2021. [Online]. Available: https://www.levada.ru/2014/06/26/iyunskie-rejtingiodobreniya-i-doveriya-3/

25. Mezhdunarodnoe vlijanie Rossii Accessed on: August 15, 2021. [Online]. Available: https://wciom.ru/analytical-reviews/analiticheskiiobzor/mezhdunarodnoe-vlijanie-rossii
26. Attitude towards the US. Accessed on: August 20, 2021. [Online]. Available: https://www.levada.ru/en/2021/04/09/attitudetowards-the-us/

27. Enemies Accessed on: August 1, 2021. [Online]. Available:

(https://www.levada.ru/en/2020/11/05/enemies-2/

28. Majority of Americans Now Consider Russia a Critical Threat. Accessed on: August 5, 2021. [Online].

Available: https://news.gallup.com/poll/247100/majorityamericans-consider-russia-critical-threat.aspx 